Uniwersytet Mikołaja Kopernika w Toruniu

Wydział Nauk Ekonomicznych i Zarzqdzania

Sylwester Bejger, Joanna Bruzda

\title{
DETEKCJA RÓWNOWAGI ZMOWY W BRANŻY Z WYKORZYSTANIEM ANALIZY FALKOWEJ - WERYFIKACJA EMPIRYCZNA
}

Z a r y s t r és c i. Artykuł zawiera empiryczne zastosowanie markera zmian strukturalnych wariancji procesu ceny rynkowej dla szeregu cen średnich Lysiny na rynku USA w latach 1990-1996. Jako metodę ekonometryczną detekcji zmian strukturalnych w wariancji zastosowano, po raz pierwszy w tym kontekście, analizę falkową. Metoda ta ma w omawianym zakresie aplikacji istotne zalety, takie jak oszczędność, jeśli chodzi o wymagane dane statystyczne, oraz bardzo dobre własności lokalizacyjne w dziedzinie czasu. Artykuł stanowi kontynuację pracy zawartej w części pierwszej, gdzie zaproponowano model teoretyczny zachowań strategicznych graczy w branży motywujący zastosowanie wymienionego markera.

S ło w a kluc z o w e : zmowa jawna i milcząca, supergra ze stałą strukturą udziałów w rynku, Lysina, wariancja ceny, analiza falkowa.

\section{WSTĘP}

W części pierwszej pracy pt. Detekcja równowagi zmowy w branży z wykorzystaniem analizy falkowej - model teoretyczny scharakteryzowano krótko branżę producentów Lysiny w okresie 1990-1996 oraz skonstruowano model teoretyczny zachowań strategicznych graczy w branży, oparty na standardowym modelu supergry z grą składową typu Cournota przy dodatkowym założeniu egzogenicznych i stałych w czasie kwot kartelowych (udziałów w rynku). Dla branż o określonych parametrach, np. branży producentów Lysiny we wspomnianym okresie, model ten może wskazywać na pewne charakterystyczne 
zaburzenia strukturalne w wariancji ceny rynkowej, wynikające z możliwości wystąpienia fazy wojny cenowej, wywołanej przez gracza niemającego intencji utrzymania lub nawiązania zmowy ze względu na zbyt niski przewidywany lub faktyczny udział w rynku oraz pewną sztywność ceny rynkowej w fazie zmowy w okresach kurczenia się rynku. Część druga pracy zawiera próbę aplikacji analizy falkowej w celu empirycznej weryfikacji poprawności ustaleń teoretycznych. Weryfikacja ta jest możliwa dzięki znanej i streszczonej w części pierwszej historii zachowań strategicznych graczy w branży. W kolejnym rozdziale streszczone zostaną dotychczasowe badania empiryczne wykorzystujące marker zmian wariancji. Rozdział drugi zawiera opis metodologii badania. W rozdziale trzecim zamieszczono wyniki badania. Artykuł kończy podsumowanie obu części pracy.

\section{DOTYCHCZASOWE BADANIA EMPIRYCZNE WYKORZYSTUJĄCE MARKER ZMIAN WARIANCJI}

Zakładając, iż model teoretyczny właściwie opisuje zachowania strategiczne w branży producentów Lysiny, można postawić następujące hipotezy badawcze:

- możliwe są zmiany reżimowe wariancji średniej ceny Lysiny ze względu na możliwość wystapienia faz wojny cenowej,

- $\quad$ w fazie zmowy wariancja powinna być niższa niż w fazie konkurencji.

Celem wykrycia tego typu zaburzeń w wariancji wykorzystano metody analizy falkowej. Podejście takie nie było dotychczas stosowane. Bazując na ustaleniach teoretycznych, można postawić hipotezę, że w fazie zmowy wariancja ceny jest średnio niższa niż w fazie konkurencji. Należy się także spodziewać reżimowych zmian wariancji przy przejściu z fazy zmowy do fazy konkurencji (wojny cenowej). Dotychczasowe prace związane z detekcją zmowy na podstawie detekcji zmian strukturalnych w wariancji obejmowały zastosowanie metod statystyki opisowej dla porównania poziomów wariancji w fazach zmowy i konkurencji (Abrantes-Metz, Froeb, Geweke, Taylor, 2006), zastosowanie dla procesu ceny rynkowej specyfikacji ARCH/GARCH wraz z dodatkową zmienną 0-1 opisującą fazy zmowy i konkurencji (Bolotova, Connor, Miller, 2008) oraz aplikację przełącznikowego modelu Markowa typu MS (M) (AR (p)) GARCH (p, q) dla wariancji i/lub średniej (stałej) procesu ceny (Bejger, 2009). Dwa ostatnie artykuły są tym bardziej interesujące, iż dotyczą także kartelu producentów Lysiny. W pracy (Abrantes-Metz, Froeb, Geweke, Taylor, 2006) przedmiotem badań był kartel dostawców mrożonych ryb. Istnienie i funkcjonowanie kartelu zostało potwierdzone przez władze. W trakcie badania stwierdzono, że w czasie trwania fazy zmowy (przed odkryciem kartelu) wariancja ceny rynkowej (proponowanej 
na przetargach przez zmawiających się) była istotnie niższa niż po upadku kartelu. Hipotezą uzasadniającą badanie był model supergry z równowagą typu SPPE. W artykule Bolotova, Connor, Miller (2008) wykorzystano specyfikację ARCH/ /GARCH w celu zbadania zaburzeń w wariancji i średniej procesu ceny rynkowej Lysiny w czasie faz konkurencji i zmowy. Wpływ ten opisany był poprzez zmienne 0-1 dla faz kartelu i konkurencji. Uzyskano statystycznie istotną niższą średnią wariancję w okresach zmowy niż w fazach konkurencji. Należy jednak podkreślić, iż wydzielenie faz obu typów (celem specyfikacji zmiennych 0-1) odbyło się w oparciu o dostępne a posteriori dowody z postępowania w sprawie kartelu. $\mathrm{W}$ tym samym artykule zbadano kartel producentów kwasku cytrynowego, nie uzyskując wskazań o niższej wariancji w fazie zmowy. Podstawą teoretyczną badania markera była równowaga typu SPPE. W pracy Bejger (2009) wykorzystano model przełącznikowy typu Markowa w celu detekcji momentów zmian w poziomie wariancji i średniej procesu ceny Lysiny. Uzyskano potwierdzenie istnienia dwu reżimów wariancji i wysokiego prawdopodobieństwa przebywania procesu w reżimie o niższej wariancji szczególnie w okresie drugiej fazy zmowy. Badanie to wydaje się ważne z uwagi na brak założeń co do momentów przełączania. Detekcja tych momentów częściowo potwierdziła znaną z dowodów procesowych historię działania kartelu.

\section{METODOLOGIA ANALIZY FALKOWEJ}

Zakładając, iż model teoretyczny właściwie opisuje zachowania strategiczne w branży producentów Lysiny, można postawić następujące hipotezy badawcze:

- możliwe są zmiany reżimowe w wariancji ceny Lysiny ze względu na możliwość wystąpienia różnych faz wojny cenowej,

- $\quad$ w fazie zmowy wariancja powinna być niższa niż w fazie konkurencji.

Celem wykrycia tego typu zaburzeń w wariancji wykorzystano metody analizy falkowej, które nie były dotychczas stosowane. Porównując je z wcześniej stosowanymi ekonometrycznymi metodami detekcji zmowy opartymi na markerze zmian wariancji (wymienionymi w rozdziale 1), można zwrócić uwagę na to, że analiza falkowa umożliwia wykorzystanie prostych metod wnioskowania statystycznego, pozwala na wstępną - graficzną ocenę zmian w wariancji oraz jako metoda nieparametryczna nie jest obciążona błędem specyfikacji modelu. Dodatkowo pozwala ona na wskazanie skal, w przypadku których następuje zmiana; wymaga to jednak dysponowania długimi szeregami czasowymi.

Analiza falkowa polega na dekompozycji procesu na składowe będące przesuniętymi i przeskalowanymi wersjami tzw. falki podstawowej $\psi(\cdot)$, stanowiącej funkcję o jednostkowej energii, spełniającą tzw. warunek dopuszczalności 
(Percival, Walden, 2000, s. 4). Niechdany będzie wektorpostaci $\mathbf{x}=\left(x_{0}, x_{1}, \ldots, x_{N-1}\right)$ długości $N=2^{J}$. Dla $j=1,2, \ldots, J$ oraz t $=0,1, \ldots, 2^{J-j}-1(j-$ poziom dekompozycji, $t$ - numer współczynnika falkowego) definiujemy dyskretną transformatę falkową (DWT) wektora $\mathbf{x}$ :

$$
W_{j, t}=\sum_{n=0}^{N-1} x_{n} \psi_{j, t}(n),
$$

gdzie $\psi_{j, t}(\cdot)$ są przeskalowanymi i przesuniętymi na skali diadycznej wersjami falki podstawowej, $\mathrm{tj}$.:

$$
\psi_{j, t}(x)=2^{-j / 2} \psi\left(2^{-j} x-t\right) .
$$

W przypadku popularnych falek Daubechies dla danego $j$ współczynniki falkowe $W_{j, t}$ są proporcjonalne do przyrostów średnich ruchomych dla skali $\lambda_{j}=2^{j-1}$. Dla procesu stochastycznego $X_{t}$ zmienną w czasie wariancję falkową definiuje się następująco:

$$
\sigma_{t}^{2}\left(\lambda_{j}\right)=\frac{1}{2 \lambda_{j}} \operatorname{Var}\left(W_{j, t}\right)
$$

Zakładając, że wariancja ta nie zależy od czasu', otrzymuje się dekompozycję wariancji według skal postaci (Percival, Walden, 2000, s. 296-298):

$$
\operatorname{Var}\left(X_{t}\right)=\frac{1}{2} \sum_{j=1}^{\infty} \frac{1}{\lambda_{j}} \operatorname{Var}\left(W_{j, t}\right)=\sum_{j=1}^{\infty} \sigma^{2}\left(\lambda_{j}\right) .
$$

Wariancja falkowa na poziomie $j$ odpowiadającym skali $\lambda_{j}=2^{j-1}, \sigma^{2}\left(\lambda_{j}\right)$, informuje o zmienności wahań o okresach zawartych w przybliżeniu w przedziale $2^{j}-2^{j+1}$.

W estymacji wariancji i korelacji falkowych w praktyce w miejsce DWT stosuje się jej modyfikację w postaci MODWT (ang. maximal overlap discrete wavelet transform $)^{2}$, która nie wymaga operowania szeregami długości będącej potęgą liczby 2, dostarcza bardziej efektywnego estymatora $\sigma^{2}\left(\lambda_{j}\right)$ oraz ma własność niezmienniczości ze względu na przesunięcia w czasie (Percival, Walden, 2000, s. 308-310; Gençay i in., 2002, s. 135). Nieobciążony estymator wariancji falkowej dany jest wówczas wzorem:

1 Założenie to jest spełnione także dla procesów niestacjonarnych pod warunkiem, że procesy te są zintegrowane rzędu $d$, zastosowany zaś filtr falkowy jest wystarczający do eliminacji niestacjonarności, tj. jest filtrem Daubechies lub coiflet o odpowiedniej długości - patrz Percival, Walden (2000).

2 MODWT proponuje się czytać jako 'mod WT' - zmodyfikowana WT (patrz Percival, Walden, 2000, s. 159). Inne nazwy tego przekształcenia to niezdziesiątkowana (ang. non-decimated) transformata falkowa, ciagło-dyskretna (ang. continuous-discrete) transformata falkowa czy zaczerpnięte z języka francuskiego określenie algorithme à trous. 


$$
\widetilde{\sigma}^{2}\left(\lambda_{j}\right)=\frac{1}{\widetilde{N}_{j}} \sum_{t=L_{j}-1}^{N-1} \widetilde{W}_{j, t}^{2},
$$

gdzie $\widetilde{W}_{j, t}$ są współczynnikami MODWT, $L_{j}=\left(2^{j}-1\right)(L-1)+1$ jest długością filtra falkowego dla skali $\lambda_{j}$ ( $L$ jest długością podstawowego filtra falkowego), $\widetilde{N}_{j}=N-L_{j}+1$ zaś jest liczbą współczynników niezniekształconych metodą ekstrapolacji na krańcach próby. (1- $\alpha)$-procentowy przedział ufności dla $\sigma^{2}\left(\lambda_{j}\right)$ można aproksymować następująco:

$$
\widetilde{\sigma}^{2}\left(\lambda_{j}\right) \pm \varsigma_{\frac{\alpha}{2}}\left(\frac{\hat{f}_{\widetilde{W}_{j} j}(0)}{\widetilde{N}_{j}}\right)^{0,5},
$$

gdzie $\varsigma_{\frac{\alpha}{2}}$ jest kwantylem rzędu (1- $\left.\alpha / 2\right)$ z rozkładu normalnego, $\hat{f}_{\widetilde{W}, j}(0)$ zaś jest oceną funkcji gęstości spektralnej dla kwadratów współczynników falkowych dla skali $\lambda_{j}$ w punkcie 0 .

Atrakcyjność współczynników falkowych w testowaniu zmian w zakresie wariancji wynika z dwu ich ważnych własności: po pierwsze, współczynniki falkowe są związane ze zmianami dla różnych skal i momentów czasu, a więc są nośnikami informacji na temat zmienności procesu, a po drugie, (konwencjonalna) transformata falkowa dostarcza współczynników, które można traktować jako w przybliżeniu nieskorelowane zarówno w przypadku procesów z krótka, jak i długą pamięcią, co znacznie upraszcza wnioskowanie (por. Whitcher, 1998, § 4.1.2; Percival, Walden, 2000, s. 351 i nast.). Natomiast w estymacji momentu zmiany proponuje się wykorzystanie MODWT ze względu na eliminację efektów podpróbkowania (ang. subsampling), co wiąże się z większą precyzją oceny. Poniżej prezentuje się podejście zaproponowane w rozprawie doktorskiej B. Whitchera (1998) oraz proponuje się bezpośrednią aplikację do współczynników falkowych metody Inclána i Tiao (1994). Należy zaznaczyć, że metody falkowej detekcji zmian w zakresie wariancji są dyskutowane przede wszystkim w kontekście procesów z długą pamięcią, ale - ponieważ własność przybliżonej dekorelacji zachodzi także dla procesów z krótką pamięcią - możliwe jest stosowanie tej metody w przypadku tych procesów.

Niech $\left\{W_{j, t}\right\}$ będą współczynnikami falkowymi z j-tego poziomu dekompozycji. Jesteśmy zainteresowani testowaniem hipotezy:

$$
\mathrm{H}_{0}: \operatorname{Var}\left(W_{j, L_{j}^{\prime}}\right)=\operatorname{Var}\left(W_{j, L_{j}^{\prime}+1}\right)=\ldots=\operatorname{Var}\left(W_{j, N / 2^{j}-1}\right),
$$

gdzie $L_{j}^{\prime}$ jest liczbą współczynników brzegowych przekształcenia falkowego na j-tym poziomie dekompozycji (współczynników DWT, na których wartość ma wpływ metoda ekstrapolacji na krańcach próby) ${ }^{3}$. Zakładamy następnie, że

3 Dla stosowanych dalej falek wielkości te wynoszą: 0 w przypadku falki Haara, dla d4 zaś - 1 na pierwszym poziomie dekompozycji i 2 na wyższych - por. Percival, Walden (2000), s. 136. 
dekorelacja falkowa jest efektywna w tym sensie, że współczynniki $\left\{W_{j, t}\right\}$ tworzą Gaussowski biały szum rzędu drugiego. Ponadto zakładamy, że długość filtra falkowego jest wystarczająca do eliminacji składników deterministycznych, tj. $\mathrm{E}\left(W_{j, t}\right)=0$. Sprawdzianem $\mathrm{w}$ teście wobec alternatywy postaci:

$$
\mathrm{H}_{1}: \operatorname{Var}\left(W_{j, L_{j}^{\prime}}\right)=\ldots=\operatorname{Var}\left(W_{j, k}\right) \neq \operatorname{Var}\left(W_{j, k+1}\right) \ldots=\operatorname{Var}\left(W_{j, N / 2^{j}-1}\right),
$$

gdzie $k$ jest nieznanym momentem zmiany, jest statystyka oparta na znormalizowanej skumulowanej sumie kwadratów (CUSUM dla kwadratów):

$$
W_{k}=\frac{\sum_{t=L_{j}^{\prime}}^{k} W_{j, t}^{2}}{\sum_{t=L_{j}^{\prime}}^{N / 2^{j}-1} W_{j, t}^{2}},
$$

postaci:
A. (Inclán, Tiao, 1994)
$I T=\sqrt{\frac{N_{j}^{\prime}}{2}} \max _{k=L_{j}^{\prime}, \ldots, 2^{J-j}-1}\left|W_{k}-\frac{k-L_{j}^{\prime}+1}{N_{j}^{\prime}}\right| ;$
B. (Whitcher, 1998)

$$
W=\sqrt{\frac{N_{j}^{\prime}}{2}} \max \left\{D^{+}, D^{-}\right\} \text {, }
$$

gdzie

$$
D^{+}=\max _{k=L_{j}^{\prime}, \ldots, N / 2^{j}-2}\left(\frac{k-L_{j}^{\prime}+1}{N_{j}^{\prime}-1}-W_{k}\right), \quad D^{-}=\max _{k=L_{j}^{\prime}, \ldots, N / 2^{j}-2}\left(W_{k}-\frac{k-L_{j}^{\prime}}{N_{j}^{\prime}-1}\right),
$$

a $N_{j}^{\prime}=N / 2^{j}-L_{j}^{\prime}$ jest liczbą współczynników niezniekształconych metodą ekstrapolacji na krańcach próby. W przypadku, gdy $N_{j}^{\prime}$ wynosi co najmniej 128 , we wnioskowaniu można wykorzystać rozkład zadany dystrybuantą:

$$
F(x)=1+2 \sum_{l=1}^{\infty}(-1)^{l} e^{-2 l^{2} x^{2}}
$$

(patrz: Inclán, Tiao, 1994, s. 923; Whitcher, 1998, s. 60). Małopróbkowe wartości statystyki (9) można znaleźć w pracach Whitcher (1998), Whitcher i in. (2002).

\subsection{TESTOWANIE ZMIAN W WARIANCJI - WYBÓR METODY}

Jak wspominano wcześniej, w estymacji momentu zmiany należy oprzeć się na współczynnikach $\widetilde{W}_{j, t}$ niezdziesiątkowanej transformaty falkowej. Wówczas indeks $\widetilde{k}^{*}$, dla którego odpowiednie wyrażenia w statystykach testowych osiagają swoje wartości maksymalne, wskazuje moment zmiany. Oczywiście, w statystykach tych należy odpowiednio zmodyfikować granice sumowania w taki sposób, aby uwzględnić wszystkie współczynniki niebrzegowe. I tak, statystyka w wersji Inclána i Tiao przyjmuje obecnie postać: 


$$
I T=\sqrt{\frac{N-L_{j}+1}{2}} \max _{k=L_{j}-1, \ldots, N-1}\left|W_{k}-\frac{k-L_{j}+2}{N-L_{j}+1}\right|,
$$

a wyrażenia w statystyce (9) przekształcają się w:

$$
D^{+}=\max _{k=L_{j}-1, \ldots, N-2}\left(\frac{k-L_{j}+2}{N-L_{j}}-W_{k}\right), \quad D^{-}=\max _{k=L_{j}-1, \ldots, N-2}\left(W_{k}-\frac{k-L_{j}+1}{N-L_{j}}\right),
$$

przy czym znormalizowana skumulowana suma kwadratów jest postaci:

$$
W_{k}=\frac{\sum_{t=L_{j}-1}^{k} \widetilde{W}_{j, t}^{2}}{\sum_{t=L_{j}-1}^{N-1} \widetilde{W}_{j, t}^{2}} .
$$

Moment zmiany zgodny z czasem rzeczywistym otrzymamy, korygując dodatkowo ze względu na przesunięcie fazowe $e^{4}$.

W przypadku możliwości wystąpienia kilku zmian w zakresie wariancji proponuje się (Inclán, Tiao, 1994) zastosowanie procedury określanej jako algorytm iterowanych skumulowanych sum kwadratów (ang. Iterated Cumulative Sums of Squares, ICSS), opartej na metodzie segmentacji binarnej. Zastosowanie tego algorytmu w kontekście detekcji falkowej zaproponowali Whitcher i in. (2000). Przebieg tego algorytmu można przedstawić następująco:

- Mając ciąg niebrzegowych współczynników DWT: $W_{j, L_{j}^{\prime}}, W_{j, L_{j}^{\prime}+1}, \ldots$, $W_{j, N / 2^{j}-1}$ przyjmujemy $t_{1}=L_{j}^{\prime}, t_{2}=N / 2^{j}-1$ i wyznaczamy wartość statystyki $I T$ lub $W$ dla przedziału $\left[t_{1}, t_{2}\right]$. Jeśli statystyka ta wskazuje na wystąpienie zmiany, zapisujemy moment $k^{*}$, dla którego została wyznaczona jej wartość i przechodzimy do kolejnego etapu.

- Wyznaczamy wartość statystyki testowej na lewo od $k^{*}$, tj. w przedziale $\left[t_{1}, k^{*}-1\right]$, oraz na prawo od $k^{*}$, tj. w przedziale $\left[k^{*}+1, t_{2}\right]$. Jeśli znajdujemy kolejne punkty, postępujemy z nimi podobnie - dzielimy odpowiednio przedziały i wyznaczamy wartości statystyk na mniejszych przedziałach współczynników. Postępowanie kończymy, gdy nie następuje odrzucenie hipotezy zerowej.

- Porządkujemy rosnąco znalezione punkty $k_{1}, k_{2}, \ldots, k_{n}$, przyjmując dodatkowo $k_{0}=L_{j}^{\prime}$ i $k_{j+1}=N / 2^{j}-1$. Dla każdego $j=1, \ldots, n$ przeprowadzamy test w przedziale pomiędzy sąsiednimi dla $k_{j}$ punktami zmiany, tj. w obszarze pomiędzy $k_{j-1}$ a $k_{j+1}$. Jeśli potencjalny punkt zmiany nie zostaje ponownie wykryty, odrzucamy $k_{j}$ z rozważanego zbioru. Postępowanie kontynuujemy na nowym zbiorze punktów i kończymy ostatecznie, gdy nie następują redukcje w liczbie wykrytych zmian.

${ }^{4} \mathrm{~W}$ przypadku filtrów stosowanych dalej w części empirycznej ocenę momentu zmiany w czasie rzeczywistym, przy założeniu, że czas ten numerujemy od 1, otrzymujemy: w przypadku falki Haara bez modyfikacji oceny $\widetilde{k}^{*}$, w przypadku zaś falki d4 - odejmując 1 od $\widetilde{k}^{*}$. 
W celu wyboru właściwego sposobu implementacji prezentowanych metod warto przedyskutować ich własności statystyczne. Po pierwsze, falki o mniejszym nośniku (krótsze filtry falkowe) mają lepsze własności lokalizacyjne z analiz symulacyjnych prezentowanych w doktoracie Whitchera (1998) wynika, że lokalizacja momentu zmiany jest obarczona większym błędem dla dłuższych filtrów falkowych. Po drugie, współczynniki falkowe na drugim poziomie dekompozycji wymagają większych SNR (ang. signal to noise ratio), aby osiągnąc ten sam poziom dokładności, co na pierwszym poziomie zarówno w zakresie detekcji zmiany, jak i jej lokalizacji - stąd należy wykorzystywać przede wszystkim pierwsze poziomy dekompozycji. Inne wnioski z analiz symulacyjnych są następujące: ocena momentu zmiany jest lekko obciążona w kierunku środka próby (Inclán, Tiao, 1994; Whitcher, 1998), w teście stałości wariancji falki Haara, d4 i la8 dostarczają zbliżonych częstości odrzuceń w teście względem jednej i dwu zmian dla szerokiego przedziału wartości parametru $d$ integracji ułamkowej $(0,05-0,45)$, zwłaszcza jeśli użyto małopróbkowych wartości krytycznych, a test przeprowadzano na niskich (1-2) poziomach dekompozycji (Whitcher, 1998; Whitcher i in., 2002). Oczywiście, falki Daubechies ${ }^{5}$ o większym nośniku pozwalają analizować procesy niestacjonarne o bardziej skomplikowanej strukturze, ale - jednocześnie - dają mniejszą liczbę możliwych do wykorzystania współczynników. W przypadku badanego szeregu nie analizujemy wyższych poziomów dekompozycji także dlatego, że byłoby tam maksymalnie 19 współczynników (więc jest nikła szansa, że wykryte zostaną aż dwa momenty zmiany), a ponadto, chcąc przeprowadzić $j$-poziomową analizę falkową bez konieczności dopisywania dodatkowych obserwacji, powinniśmy dysponować ciagiem długości podzielnej przez $2^{j}$ (długość naszego ciagu - 78 - nie pozwala na analizę na wyższych poziomach bez dopisywania dodatkowych obserwacji). Podsumowując, w analizie zostaną zastosowane dwie falki: Haara i d4, dające filtry o długości 2 i 4 . W testowaniu występowania zmiany w zakresie wariancji posłużymy się pierwszym poziomem dekompozycji.

\section{BADANIE EMPIRYCZNE}

W pierwszym etapie analizy wykonano wykresy MODWT oraz wariancji falkowych w wersji rolling. Na wykresie 1 naniesiono współczynniki MODWT uzyskane falką Haara na 4 poziomach dekompozycji wraz ze współczynnikami skalującymi z czwartego poziomu oraz oryginalnym szeregiem czasowym. Wielkości te są przemieszczone na osi czasu tak, aby zniwelować przesunięcie fazowe.

\footnotetext{
5 Na temat falek Daubechies patrz: Daubechies, 1992; Percival, Walden, 2000.
} 


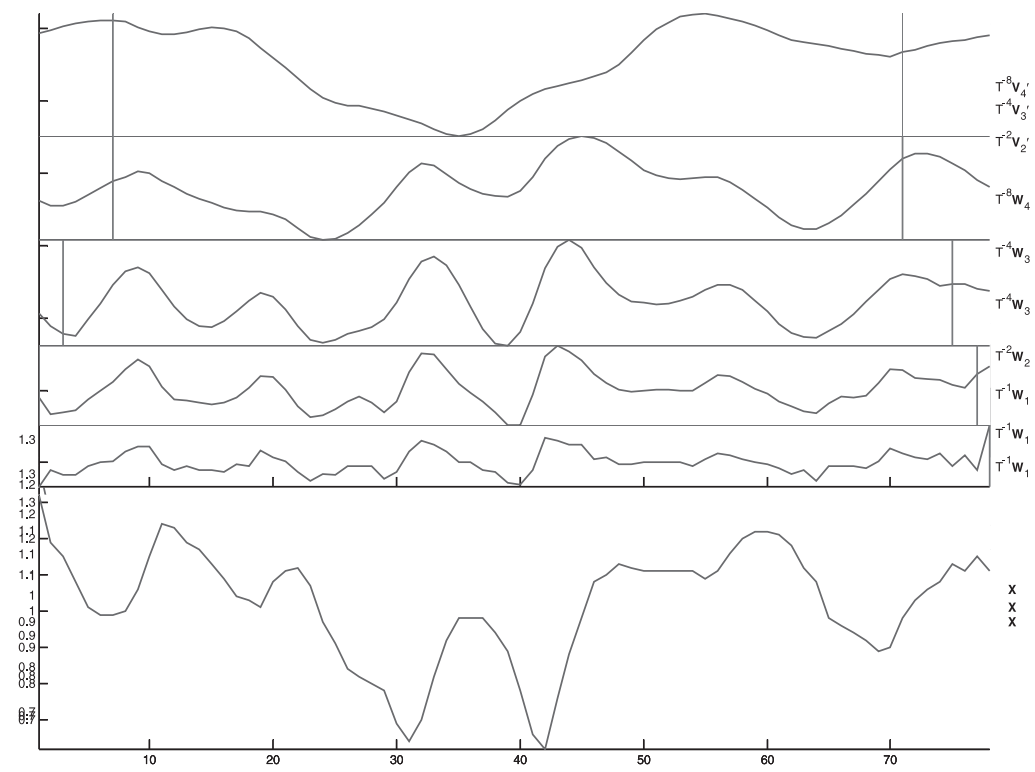

Wykres 1. Współczynniki falkowe, współczynniki skalujące i oryginalny szereg czasowy. Linie pionowe oddzielają współczynniki zniekształcone metodą ekstrapolacji na krańcach próby

Źródło: opracowanie własne.

Wykresy 2 i 3 przedstawiają wariancje falkowe w wersji rolling, tj. w ich wersji lokalnej, dla małych porcji współczynników falkowych, przesuwanych na osi czasu, wraz z 95-procentowymi przedziałami ufności, estymowane na podstawie MODWT. W obliczeniach pominięto wszystkie współczynniki brzegowe
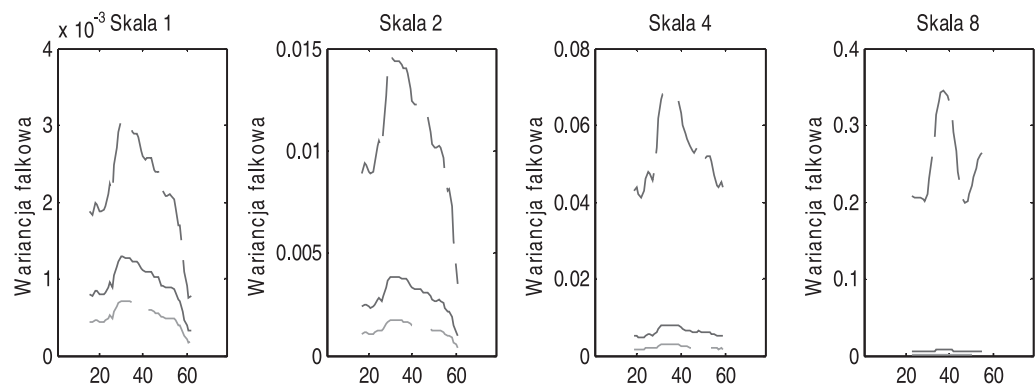

Wykres 2. Rollowane wariancje falkowe wraz z 95-procentowymi przedziałami ufności - falka Haara, okno 30

Źródło: opracowanie własne. 

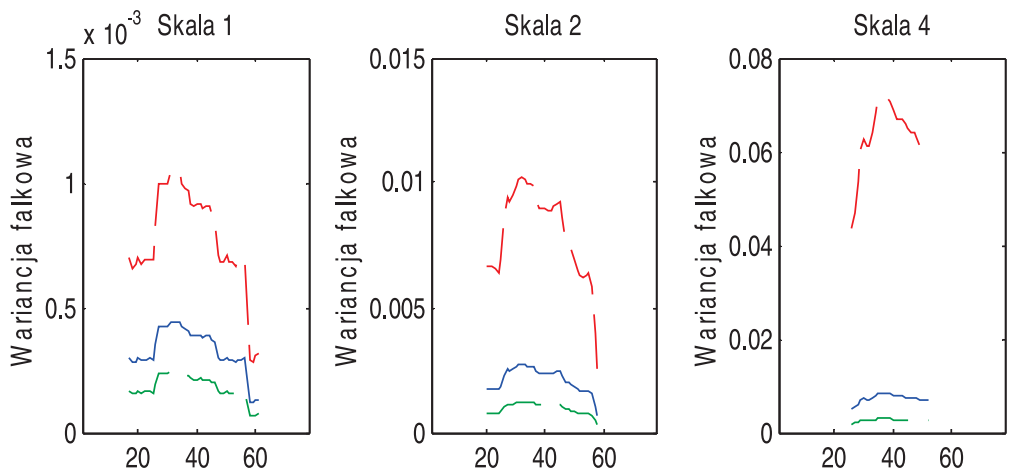

Wykres 3. Rollowane wariancje falkowe wraz z 95-procentowymi przedziałami ufności - falka d4, okno 30

Źródło: opracowanie własne.

(tj. współczynniki, na wartość których wpływ miała metoda ekstrapolacji na krańcach próby). Widać dwa momenty zmiany: około obserwacji 28 i drugi położony dalej.

Tabela 1. Testowanie występowania zmiany w zakresie wariancji - falka Haara

\begin{tabular}{|l|c|c|c|}
\hline \multicolumn{1}{|c|}{ Metoda - etap } & Statystyka & $\begin{array}{c}\text { Nr współczynnika DWT } \\
\left(k_{j}\right)\end{array}$ & $\begin{array}{c}\text { Detekcja momentu } \\
\text { zmiany za pomocą } \\
\text { MODWT }\end{array}$ \\
\hline IT - pierwszy punkt zmiany & $\mathbf{1 , 4 1 4 4 ^ { \star * }}$ & $\mathbf{2 2}\left(\boldsymbol{k}_{\mathbf{f}}\right)$ & $\mathbf{4 5}$ \\
\hline W - pierwszy punkt zmiany & $\mathbf{1 , 3 4 5 8 ^ { \star * }}$ & 10 & $\mathbf{2 2}\left(\boldsymbol{k}_{1}\right)$ \\
\hline $\begin{array}{l}\text { IT - drugi punkt zmiany, } \\
\text { szukany na lewo od } \\
\text { pierwszego }\end{array}$ & 0,4627 & 18 & 38 \\
\hline $\begin{array}{l}\text { W - drugi punkt zmiany, } \\
\text { szukany na lewo od } \\
\text { pierwszego }\end{array}$ & 0,7356 & 27 & 61 \\
\hline $\begin{array}{l}\text { IT - drugi punkt zmiany, } \\
\text { szukany na prawo od } \\
\text { pierwszego }\end{array}$ & 0,5335 & 34 & 61 \\
\hline $\begin{array}{l}\text { W - drugi punkt zmiany, } \\
\text { szukany na prawo od } \\
\text { pierwszego }\end{array}$ & 0,8494 & & 38 \\
\hline
\end{tabular}

IT - test w wariancie Inclána i Tiao; $\mathrm{W}$ - test w wariancie Whitchera; asymptotyczne wart. kryt.: 1,224 (10\%), 1,358 (5\%), 1,628 (1\%), małopróbkowe wart. kryt. (Whitcher, 1998): $n=16$ - 1,135 (10\%), 1,265 (5\%), 1,508 (1\%), $n=32-1,157$ (10\%), 1,293 (5\%), 1,553 (1\%);

małopróbkowe wart. kryt. (Inclán, Tiao, 1994): $n=100$ - 1,14 (10\%), 1,27 (5\%), 1,52 (1\%); numeracja współczynników DWT: $0,1, \ldots, 38$; moment zmiany podany w czasie rzeczywistym.

Źródło: obliczenia własne. 
Tabela 2. Testowanie występowania zmiany w zakresie wariancji - falka d4

\begin{tabular}{|l|c|c|c|}
\hline \multicolumn{1}{|c|}{ Metoda - etap } & Statystyka & $\begin{array}{c}\text { Nr współczynnika DWT } \\
\left(k_{j}\right)\end{array}$ & $\begin{array}{c}\text { Detekcja momentu } \\
\text { zmiany za pomocą } \\
\text { MODWT }\end{array}$ \\
\hline IT - pierwszy punkt zmiany & $\mathbf{1 , 1 2 9 7}$ & $\mathbf{2 3}\left(\boldsymbol{k}_{2}\right)$ & $\mathbf{4 2}$ \\
\hline W - pierwszy punkt zmiany & 1,0583 & 23 & 42 \\
\hline $\begin{array}{l}\text { IT - drugi punkt zmiany, } \\
\text { szukany na lewo od } \\
\text { pierwszego }\end{array}$ & $\mathbf{1 , 2 2 4 1 ^ { * }}$ & $\mathbf{2 0}\left(\boldsymbol{k}_{\mathbf{1}}\right)$ & $\mathbf{2 8}$ \\
\hline $\begin{array}{l}\text { W - drugi punkt zmiany } \\
\text { szukany na lewo od } \\
\text { pierwszego }\end{array}$ & $\mathbf{1 , 5 2 5 6 ^ { * * * }}$ & $\mathbf{2 0}\left(\boldsymbol{k}_{\mathbf{1}}\right)$ & $\mathbf{2 8}$ \\
\hline $\begin{array}{l}\text { IT - drugi punkt zmiany, } \\
\text { szukany na prawo od } \\
\text { pierwszego }\end{array}$ & 1,0331 & 34 & 63 \\
\hline $\begin{array}{l}\text { W- drugi punkt zmiany, } \\
\text { szukany na prawo od } \\
\text { pierwszego }\end{array}$ & 0,694 & 34 & 63 \\
\hline
\end{tabular}

IT - test w wariancie Inclána i Tiao; $\mathrm{W}$ - test w wariancie Whitchera;

asymptotyczne wart. kryt.: 1,224 (10\%), 1,358 (5\%), 1,628 (1\%),

małopróbkowe wart. kryt. (Whitcher, 1998): $n=16$ - 1,135 (10\%), 1,265 (5\%), 1,508 (1\%),

$n=32-1,157$ (10\%), 1,293 (5\%), 1,553 (1\%);

małopróbkowe wart. kryt. (Inclán, Tiao, 1994): $n=100$ - 1,14 (10\%), 1,27 (5\%), 1,52 (1\%);

numeracja współczynników DWT: 1, .., 38; oznaczenie numerów współczynników wskazujących na wystąpienie zmiany w porządku rosnącym; moment zmiany po dostosowaniu do czasu rzeczywistego.

Źródło: obliczenia własne.

Następnym etapem było testowanie zmian strukturalnych w wariancji metodami falkowymi - bezpośrednia aplikacja metody Inclána i Tiao do współczynników DWT oraz testowanie zgodnie z metodą falkową Whitchera. Wyniki obu badań podsumowują tabele 1 (zob. s. 36) i 2.

Sprawdzono także wystąpienie kolejnego punktu zmiany, stosując falkę d4. Tym razem oceniono współczynniki o numerach z przedziału [1, 20). Odpowiednie statystyki wyniosły: 0,4106 (IT), 0,6290 (W), wskazując na brak kolejnej zmiany w zakresie wariancji. Falka d4 wskazuje na dwa momenty zmiany: na temat pierwszego wnioskujemy na niskim poziomie istotności, tzn. empiryczny poziom istotności jest poniżej 10\%, ale za to na temat obecności drugiego - już na poziomie $1 \%$. Obserwacje te są zgodne z przebiegiem rollowanych wariancji falkowych. Jeśli chodzi o określenie momentów zmiany, to pojawiają się pewne niejednoznaczności. Pierwszy punkt zmiany znajduje się w przedziale 42-46 (raczej bliżej 45-46, gdyż falka Haara ma lepsze własności lokalizacyjne, 
a ponadto - jak wspominano - ocena momentu zmiany jest obciążona w kierunku środka próby), drugi zaś - jak wynika z testu z użyciem falki d4 oraz z wykresów - około obserwacji 28-29.

Zgodnie $\mathrm{z}$ algorytmem ICSS punkty zmiany znalezione z użyciem falki d4 uporządkowano rosnąco i sprawdzono dodatkowo pod względem istotności w przedziałach współczynników $W_{1, j}$ dla $j$ pomiędzy $k_{j-1}$ a $k_{j+1}$, przy przyjęciu $k_{0}=L_{j}^{\prime}$ i $k_{3}=\frac{N}{2}-1$. Poprzednie obliczenia należało jedynie uzupełnić testami dla przedziału $\left[W_{1,21}, W_{1,77}\right]$. Odpowiednie statystyki wyniosły tym razem: 1,7881 (IT), 1,7587 (W), wskazując bardzo wyraźnie na wystąpienie drugiego punktu zmiany. W każdym przypadku otrzymano też potwierdzenie lokalizacji zmiany na poziomie współczynników DWT.

\subsection{INTERPRETACJA WYNIKÓW}

W celu lepszej ilustracji uzyskanych wyników na wykresie 4 przedstawiono szereg cen średnich Lysiny wraz z naniesionymi numerami obserwacji. Jak wynika z przeprowadzonego badania, momenty zmiany wariancji identyfikowane są około 28 obserwacji - wzrost wariancji oraz około 45 obserwacji - spadek

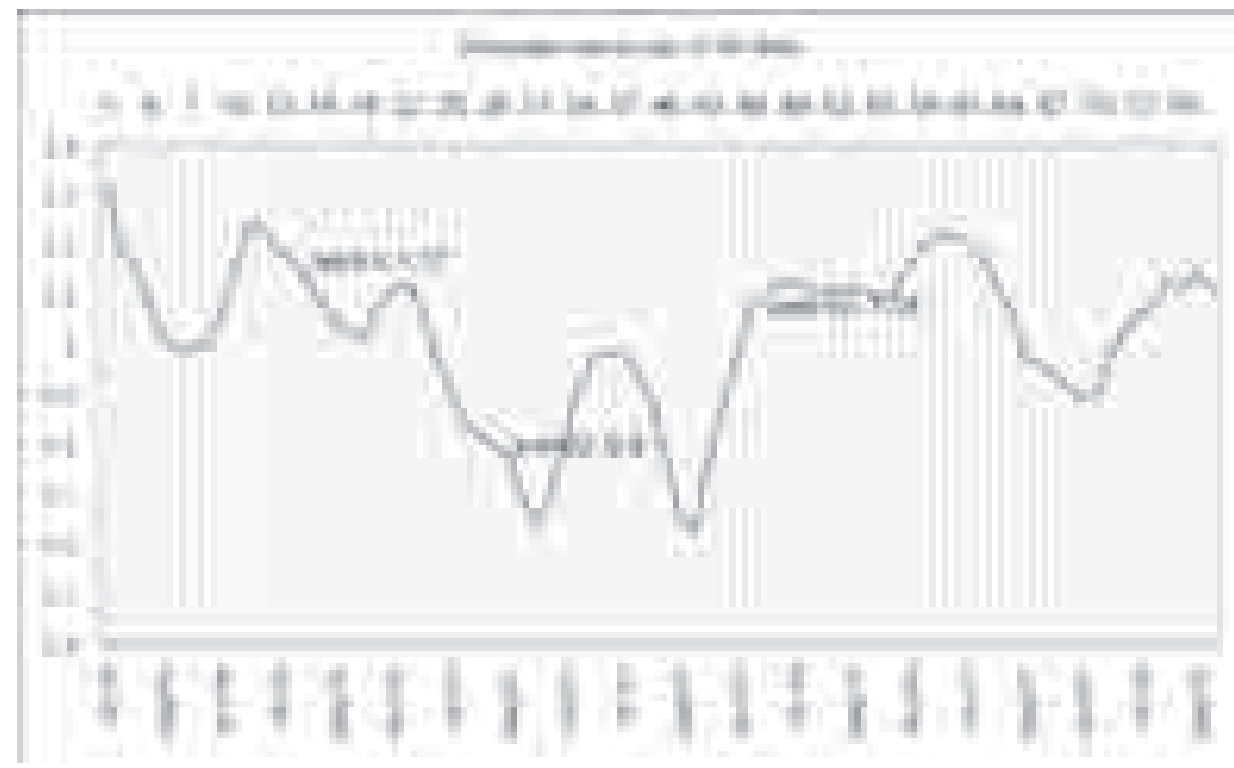

Wykres 4. Przeciętna cena Lysiny na rynku USA (na górnej osi poziomej numery obserwacji)

Źródło: opracowanie własne na podstawie danych pochodzących z: Connor, 2000, załącznik A, tabela A2. 
wariancji procesu. Tę statystyczną informację potwierdza analiza wykresów 1 i 2. Bazując na teoretycznej motywacji znacznika zmian wariancji opisanej w części pierwszej pracy (rozdział 3), należy stwierdzić, co następuje:

- do kwietnia 1992 roku nie można mówić o istotnej zmianie reżimu wariancji, a zatem okresu tego nie można uznać za faktyczną fazę wojny cenowej;

- od kwietnia 1992 do sierpnia 1993 roku można mówić o fazie istotnego wzrostu wariancji procesu, co wskazuje na wojnę cenową. Jest to okres od ogłoszenia przez ADM (dokładnie w kwietniu 1992 r.) propozycji powołania „stowarzyszenia producentów aminokwasów” do sierpnia 1993 r., czyli około 2 miesiące przed spotkaniem w Irvine;

- od września 1993 r., a zatem dokładnie miesiąc przed spotkaniem w Irvine, następuje istotny spadek wariancji procesu, co może wskazywać na zawiązanie zmowy i chęć jej utrzymania. Być może moment zmiany jest wskazany z pewnym błędem albo też gracze porozumieli się nieformalnie wcześniej, niż wskazują w zeznaniach.

Zestawiając wyniki analizy falkowej z opisanymi wcześniej, znanymi faktami z historii kartelu, należy zauważyć, iż analiza ta wskazała na istotne zmiany $\mathrm{w}$ wariancji procesu. Wykryte momenty zmiany są ściśle powiązane z ważnymi faktami z historii kartelu, a zatem można zakładać, że wskazują na zmiany zachowań cenowych graczy. Jeśli przyjąć zaproponowany model gry jako bazę teoretyczną tych zachowań, zmiany w wariancji odpowiadają fazom wojny cenowej i zmowy. W konfrontacji z dotychczas znanymi analizami funkcjonowania kartelu niniejsze badanie empiryczne prowadzi do następujących różnic w ocenie historii kartelu:

- faza wojny cenowej jest późniejsza o około 12 miesięcy,

- $\quad$ nie wyróżnia się wyraźnie pierwszej fazy zmowy cenowej.

Różnice te z jednej strony mogą być spowodowane niewielką długością szeregu danych, co uniemożliwia analizę falkową na wyższych poziomach dekompozycji, z drugiej zaś strony mogą wskazywać na inną, niż powszechnie uznana, historię zmowy w branży Lysiny6.

${ }^{6}$ Mimo całego materiału dowodowego zebranego w sprawie zawsze pozostaje możliwość, iż gracze świadomie lub nie przedstawiają inną od rzeczywistej historię zdarzeń. 


\section{PODSUMOWANIE}

W pracy, w części pierwszej, podjęto próbę stworzenia modelu teoretycznego zachowań strategicznych graczy w branży przy założeniu stałych w czasie kwot kartelowych (udziałów w rynku). Model taki może służyć do wyjaśnienia, między innymi, zachowań graczy w branży producentów Lysiny w latach 1990-1996. Model ten teoretycznie wspiera także metodę detekcji zmowy opartą na analizie wariancji procesu ceny rynkowej. Marker ten został w części drugiej pracy zastosowany do szeregu cen średnich Lysiny na rynku USA w badanym okresie. Jako metodę ekonometryczną detekcji zmian strukturalnych w wariancji zastosowano, po raz pierwszy w tym kontekście, analizę falkową. Zaproponowana metoda detekcji okazała się bardzo przydatna, wskazując na istotne zmiany reżimu wariancji oraz wykrywając precyzyjnie momenty tych zmian, ściśle powiązane z kluczowymi datami w historii kartelu. Wśród zalet analizy falkowej w proponowanej aplikacji należy wymienić:

- oszczędność specyfikacji - jako metoda nieparametryczna nie jest obciążona błędem specyfikacji modelu ekonometrycznego;

- $\quad$ prostota aplikacji - nakład pracy niezbędny do aplikacji metody do danych jest minimalny. W związku z tym metoda jest szybka w zastosowaniu;

- $\quad$ precyzyjne wskazanie momentu zmian wariancji, bez jakichkolwiek założeń co do ich lokalizacji. Metoda jest zatem całkowicie obiektywna;

- możliwość wstępnej, graficznej oceny „zachowania” wariancji z wykorzystaniem wykresów MODWT oraz rollowanych wariancji falkowych.

Jako wady analizy falkowej można wskazać relatywnie wysokie wymagania co do długości szeregu obserwacji oraz brak bezpośredniego związku metody ze strukturą strategii równowagi (jak np. w przypadku aplikacji przełącznikowego modelu Markowa typu MS-AR-GARCH).

Można zatem ocenić, iż analiza falkowa w proponowanej aplikacji może służyć jako wstępny detektor zmian w wariancji, ponieważ jej aplikacja jest tania i szybka, a wskazania precyzyjne. Tam, gdzie to jest uzasadnione teoretycznie, można następnie aplikować inne metody celem dalszej weryfikacji hipotezy zmowy w branży. Kierunkami badań, jakie zostaną podjęte, będzie modyfikacja modelu teoretycznego dla strategii przełącznikowych z innymi kodami kar oraz, w warstwie empirycznej, próba aplikacji analizy falkowej do innych szeregów cen w branżach podatnych na zmowę jawną lub milczącą. 


\section{LITERATURA}

Abrantes-Metz R., Froeb L., Geweke J., Taylor C. (2006), A variance screen for collusion, „International Journal of Industrial Organization”, 24, 467-486.

Athey S., Bagwell K., Sanchirico C. (2004), Collusion and price rigidity, „Review of Economic Studies”, 71, 317-349.

Bejger S. (2009), Ekonometryczne narzędzia detekcji równowagi zmowy w branży, „Acta Universitatis Nicolai Copernici. Ekonomia”, 39, s. 125.

Bolotova Y., Connor J. M., Miller D. J. (2008), The impact of collusion on price behavior: Empirical results from two recent cases, „International Journal of Industrial Organization”, 26, 1290-1307.

Connor J. (2000), Archer Daniels Midland: Price-fixer to the World, Staff paper No. 00-11, Department of Agricultural Economics, Purdue University, West Lafayette, IN.

Connor J. (2001), „Our customers are our enemies”: the lysine cartel of 1992-1995, „Review of Industrial Organization”, 18, 5-21.

Daubechies I. (1992), Ten Lectures on Wavelets, SIAM, Philadelphia.

Gençay R. F., Selçuk F., Whitcher B. (2002), An Introduction to Wavelets and Other Filtering Methods in Finance and Economics, Academic Press, San Diego.

Inclán C., Tiao G. C. (1994), Use of Cumulative Sums of Squares for Retrospective Detection of Changes of Variance, „Journal of the American Statistical Association”, 89, 913-923.

Percival D. B., Walden A. T. (2000), Wavelet Methods for Time Series Analysis, Cambridge University Press, Cambridge.

West K. D., Cho D. (1995), The Predictive Ability of Several Models of Exchange Rate Volatility, „Journal of Econometrics”, 69, 367-391.

Whitcher B. (1998), Assessing Nonstationary Time Series Using Wavelets, PhD thesis, University of Washington.

Whitcher B., Byers S. D., Guttorp P., Percival D. B. (2002), Testing for Homogeneity of Variance in Time Series: Long Memory, Wavelets and the Nile River, „Water Resources Research”, 38, 1054-1070.

Whitcher B., Guttorp P., Percival D. B. (2000), Multiscale Detection and Location of Multiple Variance Changes in the Presence of Long Memory, „Journal of Statistical Computation and Simulation”, 68, 65-88. 


\title{
DETECTION OF COLLUSION \\ IN AN INDUSTRY WITH APPLICATION OF WAVELET ANALYSIS - EMPIRICAL RESEARCH
}

\begin{abstract}
A bstract. In this paper we verify usefulness of a variance marker of collusion in an application to Lysine prices during well known cartel/competition episode. As an econometric method of detection of structural change in price volatility during collusive and competitive phase wavelet analysis was applied. This method, relatively new in the context of cartel detection has some attractive features for such an applications. It is not data demanding and has very good localization power in a time domain. Our work was motivated by theoretical supergame model of collusion based on fixed cartel quota exogenously provided by cartel members' agreement we developed in first part of our work.
\end{abstract}

Ke y w ords : explicit and tacit collusion, supergames, cartel detection, Lysine, price variance, wavelet analysis. 